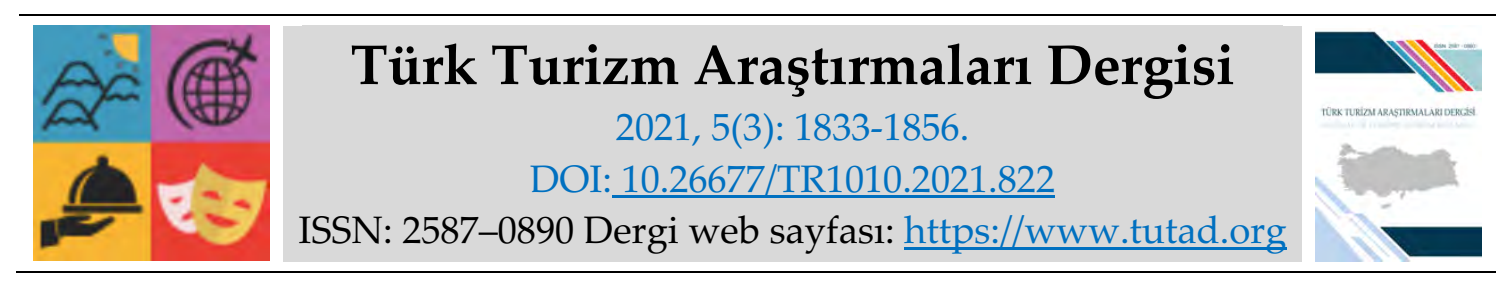

ARAȘTIRMA MAKALESI

\title{
Akdeniz Ülkelerinin Destinasyon Rekabetçilik Performanslarının Analizi: MAIRCA ve MARCOS Yöntemleri ile Bir Uygulama
}

Dr. Furkan Fahri ALTINTAŞ, Mersin İl Jandarma Komutanlığı, Mersin, e-posta: furkanfahrialtintas@yahoo.com

ORCID: https://orcid.org/0000-0002-0161-5862

Öz

Bu araştırmada, 2019 yılı için 19 Akdeniz havzası ülkenin Seyahat ve Turizm Rekabetçilik Endeksi (TTCI) bileşenlerine ait değerler üzerinden söz konusu ülkelerin destinasyon rekabetçilik performansları MAIRCA ve MARCOS yöntemleri ile ölçülmüştür. Bulgulara göre, her iki yöntem kapsamında destinasyon rekabetçilik performansı en fazla olan ilk dört ülke içinde İspanya, Fransa, İtalya ve Portekiz'in, son dört ülke içinde ise Tunus, Lübnan, Bosna Hersek ve Cezayir'in olduğu gözlenmiştir. Ayrıca TTCI kapsamında ülkelerin destinasyon rekabetçilik performans değerleri, MAIRCA yöntemine kıyasla MARCOS yöntemi ile tespit edilen ülkelerin destinasyon rekabetçilik performans değerleri ile daha fazla pozitif yönlü ilişki içinde olduğu tespit edilmiştir. Dolayısıyla bu sonuca göre, TTCI'nın MAIRCA yöntemine kıyasla MARCOS yöntemi ile daha iyi açıklanabileceği sonucuna ulaşılmıştır.

Anahtar Kelimeler: Destinasyon Rekabetçiliği, MAIRCA, MARCOS.

Makale Gönderme Tarihi: 13.06.2021

Makale Kabul Tarihi: 04.09.2021

\section{Önerilen Atıf:}

Altıntaş, F. F. (2021). Akdeniz Ülkelerinin Destinasyon Rekabetçilik Performanslarının Analizi: MAIRCA ve MARCOS Yöntemleri ile Bir Uygulama, Türk Turizm Araştırmaları Dergisi, 5(3): 18331856.

(C) 2021 Türk Turizm Araştırmaları Dergisi. 


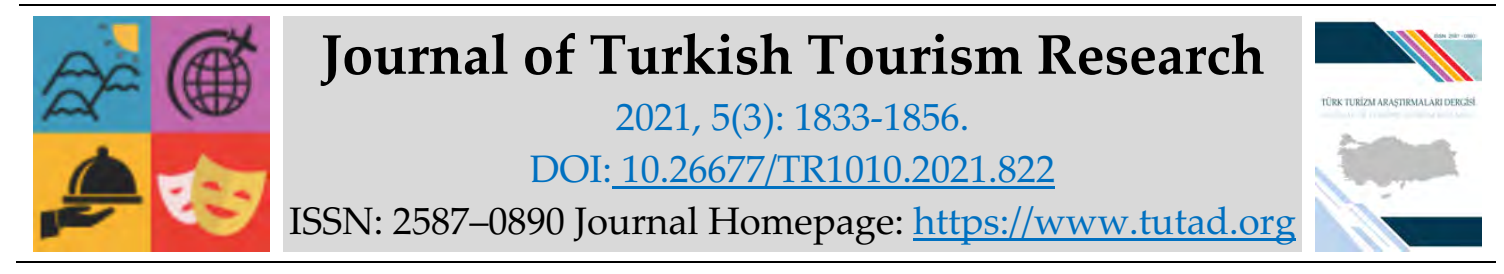

\title{
$\underline{\text { RESEARCH PAPER }}$
}

\section{Analysis of Destination Competitiveness Performance of Mediterranean Countries: An Application with MAIRCA and MARCOS Methods}

Dr. Furkan Fahri ALTINTAŞ, Mersin Provincial Gendarmerie Command, Mersin, e-mail: furkanfahrialtintas@yahoo.com ORCID: https://orcid.org/0000-0002-0161-5862

\begin{abstract}
In this research, the destination competitiveness performances of these countries were measured by MAIRCA and MARCOS methods over the values of the Travel and Tourism Competitiveness Index (TTCI) components of 19 Mediterranean basin countries for 2019. According to the findings, it was observed that Spain, France, Italy and Portugal were among the top four countries with the highest destination competitiveness performance, while Tunisia, Lebanon, Bosnia and Herzegovina and Algeria were among the last four countries within the scope of both methods. In addition, it has been determined that the destination competitiveness performance values of the countries within the scope of TTCI are more positively related to the destination competitiveness performance values of the countries determined by the MARCOS method compared to the MAIRCA method. Therefore, according to this result, it was concluded that TTCI can be better explained with the MARCOS method compared to the MAIRCA method.
\end{abstract}

Keywords: Destination Competitiveness, MAIRCA, MARCOS.

Received: 13.06 .2021

Accepted: 04.09.2021

\section{Suggested Citation:}

Altıntaş, F. F. (2021). Analysis of Destination Competitiveness Performance of Mediterranean Countries: An Application with MAIRCA and MARCOS Methods, Journal of Turkish Tourism Research, 5(3): 1833-1856.

(c) 2021 Türk Turizm Araştırmaları Dergisi. 


\section{Gíriş}

Rekabet gücü makro anlamda, ülkelerin diğer ülkelere göre daha fazla gelir, istihdam ve verimlilik sağlama kapasitesi olarak açılanmaktadır (Dursun, 2013). Günümüz dünyasında ülkeler ve diğer organizasyonlar iç ve dış piyasada tutunabilmek ve pazar paylarının sürdürülebilirliğini sağlamak için mücadele vermektedirler. Dolayısıyla rekabet gücü, ülkelerin ve diğer organizasyonların ekonomik anlamda varlıklarının sürdürmesinde en önemli unsurlardan birisidir (Meessen, 2009). Özellikle ülkelerin teknolojik altyapıları, teknoloji üretim kapasiteleri, AR-GE çalışmaları ve nitelikli çalışan sayısı ülkelerin rekabet gücünü belirleyen en önemli unsurlardır (Bucher, 2018). Ayrıca günümüzde ülkelerin rekabet gücünü belirleyen en önemli unsurlardan biri de turizm sektörüdür (Crotti vd., 2015: 3). Turizm sektörünün ülke ekonomilere oluşturduğu olumlu katkılar, turizm konusunda ülkelerin sürdürülebilir destinasyon rekabet içine girmelerine neden olmuştur (Dwyer vd., 2020: 33; Göral ve Yurtlu, 2021: 546). Bu durumda ülkelerin destinasyon rekabetçilik kapasiteleri büyük önem kazanmaktadır. Çünkü destinasyon rekabetçiliği, destinasyon yaşam tarzının tanıtılması kapsamında kârlı bir yöntemle yerel halkın refahını artırarak ve destinasyon ziyaretçilerin ilgi odağı olmasının sürdürülebilirliğini sağlayarak turizm gelirlerinin artmasında önemli bir rol oynamaktadır (Dwyer ve Kim, 2003; Ritchie ve Crouch, 2003).

Turizm sektörünün ülkelerin ekonomik iyileşmelerine olumlu katkılarının olması kapsamında ülkeler sürekli olarak kendilerinin destinasyon rekabetçilik performanslarını takip etmektedirler. $\mathrm{Bu}$ kapsamda ülkeler, destinasyon rekabetçilik performansı konusunda eksikliklerinin, yeterliliklerinin ve üstünlüklerinin farkında olurlar. Böylelikle ülkeler, bu farkındalık sayesinde destinasyon rekabetçilik performansı konusunda eksikliklerini gidermek, yeterliliklerini geliştirmek ve üstünlüklerinin sürdürülebilirliğini sağlamak ve buna göre destinasyon rekabetçilik performanslarını artırmak için uygun stratejiler, yöntemler, yönetimler ve uygulamalar sağlayabilmektedirler. Ayrıca ülkeler, birbirlerinin destinasyon rekabetçilik performanslarını da takip etmektedirler. Bu kapsamda ülkeler, destinasyon rekabetçilik performanslarını artırmak için destinasyon rekabetçilik performansları iyi olan ülkeler ile turizm konusunda işbirlikleri ve ortaklıklar sağlayabilmektedir. Dolayısıyla ülkeler her zaman kendilerinin destinasyon rekabetçilik performanslarını ölçen metriklere gereksinim duymaktadırlar.

Ülkelerin destinasyon rekabetçilik performanslarının ölçümü konusunda çeşitli ölçüm modelleri geliştirilmiştir. Bu kapsamda Croutch ve Ritchie (1994, 1995, 1999) ile Ritchie ve Crouch (1993, 2000, 2003) destinasyon rekabetçiliğin kavramsal modeli kapsamında karşılaştırmalı ve rekabetçi avantaj (kaynak varlığı ve yönetimi) durumunu açıklamışlardır. Hassan (2000), destinasyon rekabetçiliği kapsamında turizmde sürdürülebilir rekabetçilik için bir model önererek çevresel sürdürülebilirliğin önemini vurgulamıştır. Heath $(2002,2003)$ geliştirdiği sürdürülebilir destinasyon rekabetçilik modeli ile destinasyon rekabetçiliğinde insan ile ilgili unsurların öneminden bahsetmiştir. Yoon (2002), geliştirdiği turizm destinasyon rekabetçiliğin yapısal modeli üzerinden turizm paydaşları ve onların destinasyon rekabetçiliğe olan desteğinin yapısal analizini belirtmişlerdir. Dwyer ve Kim (2003) ile Kim ve Dwyer (2003) oluşturdukları entegre modeli ile destinasyon rekabetçiliği belirleyen en önemli unsurların kaynaklar, yönetim, durumsal koşul ve turizm talebinin olduğunu ifade etmişlerdir. Vengesayi (2003), geliştirdiği turizm destinasyon rekabetçiliği ve çekicilik modeli ile arz ve talep taraflı (çekicilik) rekabetçilik yöntemlerine değinmiştir. Gooroochurn ve Sugiyarto (2005), destinasyon rekabetçiliği çerçevesinde ülkelerin ve organizasyonların rekabetçilik güçlerinin izlenmesinde ekonomik etki, sosyal etki, insan kaynakları, altyapı, çevre, teknoloji, tarafsızlık ve sosyal gelişim faktörlerinin işlevlerinin analizini sağlamışlardır (Benedetti, 2010: 14'den akt. Yüzbaşığlu vd., 2017: 177). 
Belirtilen ölçüm modelleri haricinde ülkelerin destinasyon rekabetçilik performanslarını ölçen diğer bir metrik ise Dünya Ekonomik Formu (World Economic Forum - WEF) tarafından geliştirilmiş olan Seyahat ve Turizm Rekabetçilik Endeksi (Travel and Tourism Competitiveness Index - TTCI)'dir (Benedetti, 2010: 14' den akt. Yüzbaşığlu vd., 2017: 177). Söz konusu endeks ile ülkelerin destinasyon rekabetçilik performansları ilk olarak 2007 yılında ölçülmüştür (WEF, 2007). Şu an için 2007 haricinde ülkelerin destinasyon rekabetçilik performanslarının ölçümü ile ilgili olarak 2008, 2009, 2010, 2011, 2013, 2015, 2017 ve 2019 yılları için ilgili raporlar bulunmaktadır (WEF, 2019).

TTCI'nın temel amacı, dünya üzerindeki çeşitli ülkelerde seyahat ve turizm sektörünün gelişmesini dikkat çeken durumu sağlayan etmenleri ülkeler bazında ölçmektir (Eşiyok ve Hassan, 2020: 4). TTCI kapsamında veriler WEF ile birlikte çalışan ülke temsilcileri ile yapılan anket çalışmasına dayanmaktadır (Göral, 2016: 70). TTCI dört bileşen, dört bileşene bağlı 14 alt bileşen ve 14 alt bileşene bağlı 90 değişkenden oluşmaktadır. Buna göre TTCI bileşenleri, alt bileşenleri ile bileşen ve alt bileşenlerin ağırlıkları Tablo 1'de gösterilmiştir.

Tablo 1. TTCI Bileşenleri, Alt Bileşenleri ve Bileşen ile Alt bileşenlerin Ağırlıkları

\begin{tabular}{|c|c|}
\hline Bileşenler & Alt Bileşenler \\
\hline \multirow{5}{*}{ Çevresel İmkânlar (\%25) } & İş çevresi (\%5) \\
\hline & Huzur ve güvenlik (\%5) \\
\hline & Sağlık ve temizlik (\%5) \\
\hline & İnsan kaynakları ve işgücü piyasası (\%5) \\
\hline & Bilgi teknolojilerine uyum $(\% 5)$ \\
\hline \multirow{4}{*}{ Turizm Politikası ve Çevresel Şartlar (\%25) } & Seyahat ve turizmin önceliklendirilmesi $(\% 6,25)$ \\
\hline & Uluslararası açıklık $(\% 6,25)$ \\
\hline & Fiyatta rekabetçilik $(\% 6,25)$ \\
\hline & Çevresel sürdürülebilirlik $(\% 6,25)$ \\
\hline \multirow{3}{*}{ Altyapı (\%25) } & Havayolu taşımacılığı altyapısı $(\% 8,33)$ \\
\hline & Karayolu ve liman altyapisı $(\% 8,33)$ \\
\hline & Turizm hizmetleri altyapısı $(\% 8,33)$ \\
\hline \multirow{2}{*}{ Doğal ve kültürel kaynaklar (\%25) } & Doğal Kaynaklar $(\% 12,5)$ \\
\hline & Kültür varlıkları ve iş seyahatleri $(\% 12,5)$ \\
\hline
\end{tabular}

Kaynak: WEF, 2019: 85

TTCI'da bileşenler, alt bileşenler ve değişkenler 1 ile 7 arasında değer almaktadır. 1 en kötü değeri, 7 ise en iyi değeri belirtmektedir. Ayrıca ülkelerin alt bileşenlerin aritmetik ortalamaları ile bileşenler, bileşenlerin aritmetik ortalamaları ile ülkelerin TTCI kapsamında destinasyon rekabetçilik performansları hesaplanabilmektedir (WEF, 2019: 85). Buna karşın TTCI değişkenleri farklı ölçütlere göre düzenlenmiş oldukları için söz konusu değişkenlerin 1 ile 7 değerinde olması için normalizasyon işlemi sağlanmaktadır. Söz konusu normalizasyon işlemleri Tablo 2'de açıklanmıştır.

Tablo 2. TTCI Değişkenlerinin Normalizasyon İşlemleri

\begin{tabular}{lc}
\hline Değişkenler & Normalizasyon Formülü \\
\hline $\begin{array}{l}\text { Değişkenlerin yüksek değerlerinin iyi bir } \\
\text { sonuç gösterdiği durumlar }\end{array}$ & $-6 \times \frac{\text { Ülke değeri-En küçük değer }}{\text { En büyük değer-en küçük değer }}+7$ \\
$\begin{array}{l}\text { Değişkenlerin yüksek değerlerinin kötü bir } \\
\text { sonuç gösterdiği durumlar }\end{array}$ & $6 \times \frac{\text { Ülke değeri-En küçük değer }}{\text { En büyük değer-en küçük değer }}+1$ \\
\hline
\end{tabular}

Kaynak: WEF, 2019: 85'den uyarlanmıştır. 
Akdeniz bölgesinde yer alan ülkeler dünya turizm sektöründe önemli bir yere sahiptir (Davraz, 2020). Çünkü Akdeniz bölgesi, dünyanın en eski yerleşim ve uygarlık merkezlerden en önemlilerinden biri olması nedeniyle söz konusu bölge turistler için seyahat ve turizm açısından odak noktası haline gelmiştir (Bozok ve Köroğlu, 2007: 1). Dolayısıyla Akdeniz bölgesinde yer alan ülkelerin turizm faaliyetleri dünya turizm faaliyetlerini etkileyebildiğinden dolayı Akdeniz bölgesinde yer alan ülkelerin destinasyon rekabetçiliği performanslarının ölçülmesi büyük önem arz etmektedir. Bu kapsamda araştırmada Akdeniz bölgesinde yer alan 19 ülkenin (Fransa, İtalya, İspanya, Portekiz, Türkiye, Yunanistan, Hirvatistan, Slovenya, Arnavutluk, Fas, Tunus, Cezayir, Mısır, İsrail, GKRY, Malta, Lübnan, Bosna Hersek ve Karadağ) en son ve güncel olan 2019 yılı için TTCI bileşenlerine ait değerler üzerinden söz konusu ülkelerin destinasyon rekabetçilik performanslarını MAIRCA ve MARCOS çok kriterli karar verme (ÇKKV) yöntemleri ile ölçülmüştür. Karar alternatiflerinin performanslarının ölçülmesinde MAIRCA ve MARCOS yöntemleri duyarlılık ve güvenirlik seviyeleri yüksek ÇKKV yöntemleridir (Boral vd., 2020; Gigovic, 2016). Dolayısıyla araştırmada söz konusu ülkelerin destinasyon rekabetçilik performanslarının ölçülmesinde MAIRCA ve MARCOS yöntemleri tercih edilmiştir. Bu kapsamda araştırmanın literatür kısmında destinasyon rekabetçiliği ve TTCI ile ilgili olan araştırmalar belirtilmiştir. Araştırmanın sonuç, tartışma ve öneriler kısmında ise bulgular çerçevesinde tespit edilen nicel değerlere istinaden çıkarımlarda bulunup, tartışılmıştır.

\section{LİTERATÜR}

Araştırmanın literatürü iki kısımdan oluşmaktadır. Bunlardan birincisinde destinasyon rekabetçiliği ile TTCI kapsamında araştırmalar belirtilmiştir. İkincisinde ise MAIRCA ve MARCOS ile ilgili araştırmalar açıklanmıştır.

Destinasyon rekabetçiliği, turizm alanında rekabetin asıl belirleyicisi rolündedir. Bu bağlamda Hassan (2000), destinasyon rekabetçiliğini bir destinasyonun rakiplerine kiyasla pazar konumunu en kârlı konuma getirmesinde olumlu getiri sağlayan ürünleri sağlama ve bu ürünleri bütünleştirme faaliyeti olarak açıklamıştır. Ritchie ve Crouch (2000) ise, destinasyon rekabetçiliğini bir ülkenin katma değer sağlama ve buna bağlı olarak çekiciliği, varlıkları, ulaşılabilirliği ile süreçleri yönetmek ve bu ilişkileri iktisadi ve sosyal bir modelde birleştirme yeteneği olarak belirtmişlerdir (Ekin, 2004: 34).

Destinasyon rekabetçiliğin sağlanmasında turizm çekiciliğinin çok önemli bir işlevi bulunmaktadır. Bu bağlamda ülkelerin veya bölgelerin turizm destinasyon rekabetçilik performansının artırılmasına yönelik çeşitlik turizm çekicilik öğeleri incelenmiştir. Dolayısıyla literatürde turizm destinasyon rekabetçiliği kapsamında birçok çekicilik öğesi bulunmaktadır. Buhatis (2000) literatürde bulunan destinasyon rekabetçiliği çerçevesinde çekicilik konusundaki yaygın ve ortak öğeleri çekicilikler (doğal ve insan yapımı yapılar), ulaşılabilirlik (ulaşım sistemleri), koşullar (konaklama, yeme-içme, satış ve pazar), mevcut paketler (aracı kurumlarca hazırlanmış paketler), etkinlikler (destinasyonda bulunan tüm etkinlikler) ve yardımcı hizmetler olarak açıklamıştır (Ekin, 2004: 39).

TTCI literatürünün ana kaynağını, WEF tarafından oluşturulan TTCI raporlarına dayanmaktadır. Söz konusu raporlarda belirli yıllara istinaden ülkelerin destinasyon rekabetçilik performansları ölçülmüş ve ölçümlere göre ülkeler sıralanmıştır. Bu kapsamda tüm TTCI raporları kapsamında belirli yıllara göre en fazla destinasyon rekabetçilik performansı gösteren ilk 10 ülke Tablo 3'de açıklanmıştır. 
Tablo 3. Ülkelerin TTCI Raporları Kapsamında Destinasyon Rekabetçilik Performans Siralamaları

\begin{tabular}{ccccc}
\hline Sıralama & 2007 & 2008 & 2009 & 2011 \\
\hline 1 & İsviçre & İsviçre & İsviçre & İsviçre \\
2 & Avusturya & Avusturya & Avusturya & Almanya \\
3 & Almanya & Almanya & Almanya & Fransa \\
4 & İzlanda & Avustralya & Fransa & Avusturya \\
5 & ABD & İspanya & Kanada & İsveç \\
6 & Hong Kong & İngiltere & İspanya & ABD \\
7 & Kanada & ABD & İsveç & İngiltere \\
8 & Singapur & İsveç & ABD & İspanya \\
9 & Lüksemburg & Kanada & Avustralya & Kanada \\
10 & İniltere & Fransa & Singapur & Singapur \\
\hline Sıralama & 2013 & 2015 & 2017 & 2019 \\
\hline 1 & İsviçre & İspanya & İspanya & İspanya \\
2 & Almanya & Fransa & Fransa & Fransa \\
3 & Avusturya & Almanya & Almanya & Almanya \\
4 & İspanya & ABD & Japonya & Japonya \\
5 & İniltere & İngiltere & İngiltere & ABD \\
6 & ABD & İsviçre & ABD & Avustralya \\
7 & Fransa & Avustralya & Avustralya & İtalya \\
8 & Kanada & İtalya & İtalya & Kanada \\
9 & İsveç & Japonya & Kanada & İsviçre \\
10 & Singapur & Kanada & İsviçre & Avusturya \\
\hline
\end{tabular}

Kaynaklar: 2007: WEF (2007), 2008: WEF (2008), 2009: WEF (2009), 2011: WEF (2011), 2013:

WEF (2013), 2015: WEF (2015), 2017: WEF (2017), 2019: WEF (2019).

Tablo 3 incelendiğinde, İsviçre 2013 yılına kadar destinasyon rekabetçilik performansı en yüksek ülkedir. Fakat İsviçre'nin destinasyon rekabetçilik performansı 2015 yılından sonra istikrarsızlaşmış olup, 2015 yılı için 6'ıncı, 2017 yılı için 10'uncu ve 2019 yılı için ise 9'uncu sıraya gerilemiştir. Tablo 3'e göre, TTCI raporları bütünsel olarak düşünüldüğünde İsviçre, Almanya, $A B D$ ve Kanada tüm yıllara göre destinasyon rekabetçilik performansı açısından ilk 10 ülke içinde yer almıştır. Bu durum İsviçre, Almanya, ABD ve Kanada'nın diğer ülkelere göre destinasyon rekabetçilik performansına diğer ülkelere kıyasla daha önem verdiğini göstermektedir. Bunun yanında Tablo 3 değerlendirildiğinde, 2008 ve 2013 yılları için 6, diğer yıllar için 5 Avrupa Birliği üyesi ülkelerinin ilk 10 sırada olduğu gözlenmiştir. Bu durum, Avrupa Birliği tarafından destinasyon rekabetçilik konusunun dikkate alındığını açıklamaktadır. Bunların dışında Tablo 3'e göre, 2007, 2009, 2010 ve 2013 yılları için dört, 2008 yılı için 5, 2017 ve 2019 yılı için 6 ülkenin G7 grubu ülkelerinden olması dikkat çekicidir. Bu durum ise ekonomik gelişmişlik ve ekonomik büyümenin ülkelerin destinasyon rekabetçilik performansları arasında pozitif yönlü bir ilişkinin olduğunu göstermektedir.

Croitoru (2011), 2010 yılı için Romanya ve Bulgaristan ülkelerinin TTCI bileşenlerine ait değerler üzerinden ülkelerin destinasyon rekabetçilik performanslarını karşılaştırmışlardır. Araştırmada, Romanya'nın turizmde yatırımı teşvik etmek için kurumsal ortamı iyileştirmeye yönelik çabalar göstermesine rağmen söz konusu çabaların verimli bir stratejiye dayanmadığı belirlenmiştir. Dolayısıyla araştırmada, Romanya'nın elverişli coğrafi konumundan, doğal ve kültürel kaynaklarından ve yüksek kaliteli insan sermayesinden yararlanamadığı tespit edilmiştir. 
Araştırmada bunların dişında Bulgaristan'ın uluslararası pazarda rekabet avantajlarından yararlanmada kararlı olduğu ve Romanya'dan farklı olarak turizm faaliyetlerinde daha iyi sürdürülebilir stratejiler sağladığı vurgulanmıştır. Gabor vd., (2012), 2011 yılı için 27 Avrupa Birliği üyesi ülkenin TTCI alt bileşenlerine ait verileri ile söz konusu ülkelerin kümeleme analizi ile tasniflemişlerdir. Araştırmada, birinci kümede yer alan Belçika, Danimarka, Finlandiya, Fransa, Almanya, Hollanda, İsveç ve İngiltere'nin destinasyon rekabetçiliği konusunda ulusal stratejilerle kendilerini geliştirmiş oldukları bulgusuna ulaşılmıştır. İkinci küme ülkeleri olan Bulgaristan, Yunanistan, İtalya ve İspanya'nın kendilerine özgü doğal potansiyellerinin oldukları belirtilmiştir. Üçüncü küme ülkeleri olan Avusturya, GKRY, Estonya, İrlanda, Lüksemburg, Malta, Portekiz ve Slovenya'nın turizm konusunda güçlü altyapılarının oldukları tespit edilmiştir. Dördüncü küme ülkeleri olan Polonya ve Romanya'nın destinasyon rekabetçilik potansiyellerini artırmaları için altyapı bileşenine gerekli önemi vermeleri gerektiği işaret edilmiştir. Son olarak 5'inci küme ülkeleri olan Çekya, Macaristan, Letonya, Litvanya, Slovakya ülkelerinin destinasyon rekabetçilik performanslarını artırmaları için güçlü maliye politikaları sağlamaları gerektiği ifade edilmiştir. Cibinskiene ve Sinieskiene (2015), şehir turizm rekabetçiliği konusunda 18 turizm uzmanına danışarak bir ölçek geliştirmişlerdir. Söz konusu ölçek, iki bileşen ve iki bileşene bağlı 7 alt bileşenden oluşmuştur. Buna göre bileşenler iç ve dış çevre faktörleri olma üzere ikiye ayrılmıştır. İç çevre faktörlerini politik ve yasal faktörler, ekonomik faktörler, sosyal ve kültürel faktörler ile ekolojik ve doğal faktörler, dış çevre faktörlerini ise turizm girişimciliği, turizm kaynakları ve turizm altyapısı alt bileşenleri oluşturmuştur. Krstic vd. (2016), Afrika ülkelerinin 2013 yılı için TTCI ve Küresel Rekabet Endeksi değerleri üzerinden destinasyon rekabetçiliğin küresel rekabet boyutuna olan etkisini doğrusal regresyon analizi ile incelemişlerdir. Araştırmada, destinasyon rekabetçiliğin küresel rekabet boyutunu anlamlı, pozitif yönlü ve yüksek seviyede etkilediği bulgusuna ulaşılmıştır. Khan vd., (2017) 1990-2014 19 turizme odaklı ülkenin hava taşımacılığı, demiryolu taşımacılığı ve seyahat ve ulaşım hizmetleri ile destinasyon rekabetçilik değerleri üzerinden hava taşımacılığı, demiryolu taşımacılığı ve seyahat ve ulaşım hizmetleri boyutlarının destinasyon rekabetçiliği boyutuna olan etkisini panel tam modifiye regresyon yöntemi ile incelemişlerdir. Araştırmada, hava taşımacılığı ve demiryolu taşımacılı̆̆ı boyutlarının destinasyon rekabetçilik boyutunu pozitif yönlü ve anlamlı, buna karşın seyahat ve ulaşım hizmetleri negatif yönlü ve anlamlı olarak etkilediği tespit edilmiştir. Rodríguez-Díaz ve Pulido-Fernández (2019), 2017 yılı için ülkelerin TTCI ve Sürdürülebilir Gelişme Endeksi verileri kapsamında destinasyon rekabetçilik boyutunun sürdürülebilir gelişme boyutuyla olan ilişkiyi doğrusal regresyon analizi ile ölçmüşlerdir. Araştırmada, destinasyon rekabetçiliği ve sürdürülebilir gelişme arasında pozitif yönlü ve anlamlı bir ilişki olduğu tespit edilmiştir. Eşiyok ve Hassan (2020), 2015-2019 zaman aralığında Türkiye, Yunanistan, İtalya, Fransa, İspanya, Fas, Tunus ve Misır ülkelerinin TTCI'da bulunan bileşen değerleri üzerinden destinasyon rekabetçilik seviyelerini incelemişlerdir. Araştırma sonucuna göre, Akdeniz bölgesinde yer alan Avrupa destinasyonlarının rekabet gücünün, Türkiye ve Kuzey Afrika ülkelerinin destinasyon rekabetçilik performanslarına kıyasla daha fazla olduğu bulgusuna ulaşılmıştır. Güllü ve Yılmaz (2020), 2019 yılı için 10 Akdeniz ülkesinin TTCI alt bileşen değerleri üzerinden söz konusu ülkelerin destinasyon rekabetçilik performanslarını Entropi tabanlı EDAS yöntemi ile ölçmüşlerdir. Araştırma sonucuna göre, ülkelerin destinasyon rekabetçilik performansı Fransa, İspanya, İtalya ve Portekiz, Yunanistan, Hırvatistan, Tunus, Türkiye, Fas ve Mısır olarak sıralanmıştır. Manap Davras (2020) 2019 yılı için 16 Akdeniz ülkesinin TTCI raporunda alt bileşenlerine ait değerler üzerinden söz konusu ülkelerin destinasyon ve rekabetçilik performanslarını TOPSIS ve VIKOR yöntemleri ile ölçmüşlerdir. Araştırma sonucuna göre, TOPSIS yöntemi kapsamında destinasyon rekabetçilik performansı en iyi olan ilk dört ülkenin İspanya, Yunanistan, İtalya ve Fransa, son dört ülkenin ise Malta, Lübnan, İsrail ve Cezayir olduğu tespit edilmiştir. VIKOR yöntemi kapsamında ise ilk dört ülkenin İspanya, 
Yunanistan, GKRY ve Fransa, son dört ülkenin ise Ürdün, Lübnan, İsrail ve Cezayir olduğu gözlenmiştir. Bütünsel olarak değerlendirildiğinde her iki yönteme göre destinasyon rekabetçilik açısından en fazla performansa sahip olan ülkelerin İspanya, Fransa ve Yunanistan, en az performansa sahip olan ülkelerin ise Lübnan, İsrail ve Cezayir olduğu belirlenmiştir. Türkiye'nin her iki yönteme göre destinasyon rekabetçiliği sıralamasında orta sıralarda yer aldığ belirlenmiştir. Nzmfar vd., (2020), Ortadoğu ülkelerinin 2015 ve 2017 yıllarına ait TTCI alt bileşen değerleri üzerinden söz konusu ülkelerin yıllara göre destinasyon rekabetçilik performanslarını ölçmüştür. Araştırma sonucuna göre, her iki yıl için Mısır, İran, Kuveyt, Lübnan ve Yemen ülkelerinin destinasyon rekabetçilik performanslarının düşük seviyede olduğu gözlenmiştir. Göral ve Yurtlu (2021), 2019 yılı için TTCI raporunda bulunan 140 ülkenin alt bileşen değerleri üzerinden söz konusu ülkeleri 5 gruba ayırarak (1. Grup: Çok iyi (1'inci ve 30'uncu sıra aralığı, 2. Grup: İyi (31'inci ve 60'ıncı sıra aralığı), 3. Grup: Orta (61'inci ve 90'ıncı sıra aralığı, 4. Grup: Zayıf (91'inci ve 120 'inci sıra aralığı, 5. Grup: Çok zayıf (121'inci ve 140'ıncı sıra aralığı) Türkiye'nin destinasyon rekabetçilik performansını incelemişlerdir. Bu bakımdan Türkiye'nin doğal ve kültürel kaynaklar açısından çok iyi, altyapı ile turizm politikaların etkinleştirilmesi açısından iyi kategoride yer aldığı tespit edilmiştir. Fakat Türkiye'nin çevresel faktörler açısından orta düzeyde olduğu sonucuna ulaşılmıştır.

Literatürün ikinci bölümü kapsamında ise Gigović (2016), Sırbistan'da en uygun mühimmat deposu yer seçim problemini DEMATEL ve ANP tabanlı MAIRCA yöntemi ile çözmüşlerdir. Araştırma sonucuna göre, Sırbistan'da en uygun mühimmat deposu yerinin Karpat bölgesinin olduğu tespit edilmiştir. Ayrıca araştırma kapsamında duyarlılık analizi verilerine göre DEMATEL ve ANP tabanlı MAIRCA yönteminin kararlı olduğu tespit edilmiştir. Pamućar vd., (2017), Belgrad'da şehir hizmetleri için en uygun ihale seçimini DEMATEL ve ANP tabanlı MAIRCA yöntemi ile belirlemişlerdir. Araştırmada kriter ağırlıkları birbirinden farklı olmak üzere 36 senaryoya istinaden sıralamalarının birbirleriyle olan ilişkilerin anlamlı, pozitif yönlü ve yüksek seviyede olduğu belirlenmiş ve buna göre şehir hizmetleri ihalelerinde DEMATEL ve ANP tabanlı MAIRCA yönteminin kullanabileceği sonucuna ulaşılmıştır. Tesić ve Božanić (2018) Sırp ordusunun ideal su tanklarının yer problemini MAIRCA yöntemi ile çözmüşlerdir. Araştırmada, duyarlılık analizlerine göre Sırp ordusunun su tanklarının yerlerinin seçiminde MAIRCA yönteminin uygulanabilir olduğu belirlenmiştir. Ayçin ve Orçun (2019), Türkiye'de 2016 ve 2017 yılları için bankaların performanslarını ENTROPİ tabanlı MAIRCA yöntemi ile ölçmüşlerdir. Araştırmada, her iki yıla göre en başarılı bankanın Ziraat Bankası, en az başarılı bankanın ise Türkiye Vakıflar Bankası'nın olduğu gözlenmiştir. Badi ve Pamućar (2020) Libya ülkesinde demir-çelik sektöründe faaliyet gösteren tedarikçilerin seçim problemini Gri İlişkisel Analiz (GİA) tabanlı MARCOS, VIKOR ve TOPSIS yöntemleri ile çözmüşlerdir. Araştırmada, en uygun tedarikçi sıralaması açısından GİA tabanlı MARCOS yönteminin en fazla GİA tabanlı VIKOR yöntemi ile tutarlı olduğu bulgusuna ulaşılmıştır. Boral vd. (2020), arıza modu ve etki analizine göre mühendislik uygulamalarının hata modlarının risk seviyelerini bulanık AHP tabanlı bulanık MAIRCA yöntemi ile sıralamışlardır. Bulgulara göre, kriter ağırlıkları birbirinden farklı 6 senaryoya istinaden hata modlarının risk seviyelerinin sıralamaları arasında değişiklikler olduğu gözlenmiştir. Bu kapsamda araştırmaya göre, mühendislik alanında bulanık AHP tabanlı bulanık MAIRCA yönteminin hata mod risk seviyelerinin sıralamalarında uygulanabileceği tespit edilmiştir. Božanić (2020) Sırp ordusunun uygun kamp alanlarının seçim problemini LWBA tabanlı Z-Z-MAIRCA, Z-MABAC ve Z-VIKOR yöntemleri ile çözmüşlerdir. Araştırma sonucuna her üç yönteme göre en uygun kamp alan seçim yerlerinin sıralamalarının genel anlamda birbirinden farklı olduğu gözlenmiştir. Buna karşın her üç yönteme göre kamp alanları skorları arasında pozitif yönlü, anlamlı ve yüksek ilişkiler olduğu tespit edilmiştir. Stević ve Brković (2020) periyodik ücretlendirme ile çalışanların motivasyon artırma yöntemlerinin seçim problemini FUCOM tabanlı MARCOS, SAW, ARAS, WASPAS, EDADS, COCOSO, MABAC ve 
TOPSIS yöntemleri ile ölçmüşlerdir. Araştırma sonucuna göre, FUCOM tabanlı MARCOS yöntemi kapsamında söz konusu motivasyon artırma yöntemlerinin performans değerleri en fazla FUCOM tabanlı TOPSIS yöntemi kapsamında performans değerleri ile anlamlı, pozitif yönlü çok yüksek nicelikte ilişki içinde olduğu sonucuna ulaşılmıştır. Stević vd. (2020), Bosna Hersek'te sağlık endüstrisi için tedarikçi seçim problemini MARCOS yöntemi ile çözmüşlerdir. Araştırma sonucuna göre, kriter ağırlıkları değiştirilerek 21 senaryoya istinaden tedarikçi sıralamaları arasında önemli değişikliler olmadığı ve buna göre MAIRCA yönteminin sağlık endüstrisi tedarikçi seçiminde duyarlı olmadığı, fakat güvenilir ve kararlı olduğu tespit edilmiştir. Ulutaş vd., (2020) CCSD ve ITARA tabanlı MARCOS, WASPAS, ARAS ve GİA yöntemlerine göre küçük ev aletleri için optimal depo seçim problemini çözmüşlerdir. Araştırmada, CCSD ve ITARA tabanlı MARCOS yöntemi ile belirlenen en uygun depo siralamasının, en fazla CCSD ve ITARA tabanlı WASPAS yöntemi ile belirlenen en uygun depo seçimi sıralamasıyla tutarlı olduğu sonucuna ulaşılmıştır.

Literatürü toparlamak gerekirse, ülkelerin TTCI kapsamında destinasyon performanslarının incelenmesine yönelik olarak pek çok araştırmaya rastlanılmıştır. Dolayısıyla bu durum, ülkeler açısından destinasyon rekabetçilik performanslarının önemli olduğunu göstermektedir. Ayrıca ÇKKV literatürü değerlendirildiğinde, MAIRCA ve MARCOS yöntemlerini kapsamında çalışmaların kısıtlı olduğu gözlenmiştir. Bu kapsamda sınırlı araştırmalara rağmen MAIRCA ve MARCOS yöntemleri ile ilgili olan çoğu araştırmada söz konusu yöntemlerin güvenilir olduğu saptanmıştır. Buna göre, MAIRCA ve MARCOS yöntemleri ile karar alternatiflerinin seçim problemine veya performanslarının ölçülmesine yönelik daha çok araştırmanın yapılması gerekli olduğu değerlendirilmiştir.

\section{YÖNTEM}

\section{Araştırmanın Veri Seti, Kısıtı, Önemi ve Analizi}

Akdeniz'e kıyısı bulunan toplam 21 ülke bulunmaktadır. Bu ülkelerden Suriye ve Libya'nın 2019 yılının TTCI raporunda destinasyon rekabetçilik performansları açıklanmadığından söz konusu ülkeler araştırma kapsamına alınmamıştır. Dolayısıyla araştırmanın amacına yönelik olarak Akdeniz kıyısında bulunan diğer 19 ülkenin en son ve güncel olan 2019 yılının TTCI raporunda bulunan bileşenlere ait değerler üzerinden söz konusu ülkelerin destinasyon rekabetçilik performansları MAIRCA ve MARCOS yöntemleri ile ölçülmüştür. Araştırmanın kısıtı kapsamında çalışmada yalnızca Akdeniz havzası ülkelerinin destinasyon rekabetçilik performansları ölçülmüştür. Ayrıca MAIRCA ve MARCOS yöntemleri kapsamında araştırmalar kısıtlı olduğu için söz konusu araştırmanın literatüre katkı sağladığı değerlendirilmiştir. Araştırmada kolaylık sağlaması açısından TTCI bileşenlerin kısaltmaları Tablo 4'de gösterilmiştir.

Tablo 4. TTCI Bileşenleri ve Bileşenlerin Kısaltmaları

\begin{tabular}{lc}
\hline Bileşenler & Kısaltma \\
\hline Çevresel Faktörler & TTCI1 \\
Turizm Politikaları ve Koşulların Etkinleştirilmesi & TTCI2 \\
Altyapı & TTCI3 \\
Doğal ve Kültürel Kaynaklar & TTCI4 \\
\hline
\end{tabular}




\section{MAIRCA Yöntemi}

MAIRCA yöntemi, gerçek sonuç ve teorik çözüm arasındaki farkın belirlenmesi temeline dayanmaktadır. MAIRCA yönteminde, bütün karar alternatiflerinin her bir kritere göre ölçülen farkları toplanmaktadır. İşlemler sonucunda, her bir karar alternatifin gerçek değer ve teorik değer arasındaki farklar belirlenir ve farkı en az olan karar alternatifi tercih edilecek olan veya performansı en fazla olan ideal alternatif olarak değerlendirilir (Ecer, 2020: 265). Buna göre MAIRCA yönteminin uygulama aşamaları aşağıda belirtilmiştir (Chatterjee vd., 2018: 109-110; Ayçin ve Güçlü, 2019: 296-298; Ulutaş, 2019: 1471-1472; Boral, 2020: 8; Ecer, 2020: 266-269; Zolfani vd., 2020: 107; Aksoy, 2021: 5).

1. Aşama: Başlangıç Karar Matrisinin Sağlanması

$$
\begin{gathered}
C_{1}, C_{2} \ldots C_{n} \\
X=\left[d_{i j}\right]=\underset{A_{1}}{A_{2}} \\
\vdots \\
A_{m}
\end{gathered}\left[\begin{array}{cccc}
x_{11} & x_{12} \ldots . & x_{1 n} \\
x_{21} & x_{22} \ldots . & x_{2 n} \\
\vdots & \vdots & \vdots \\
x_{m 1} & x_{\mathrm{m} 2} \ldots . & x_{m n}
\end{array}\right]_{m \times n}
$$

Karar matrisinde yer alan $d_{i j}$ değeri i. karar alternatifin j. kriterdeki değerini açıklamaktadır. $B u$ karar matrisi, $n$ kriterden ve $m$ tane alternatiften $\left(A_{i} ; i=1,2, \ldots, m\right)$ oluşmaktadır.

\section{Aşama: Teorik Değerlendirme Hesabı}

$\mathrm{Bu}$ aşamada karar alternatiflerinin her birinin aynı ihtimalle gerçekleşeceği gibi düşünülür. Bu kapsamda m toplam karar alternatif sayısı belirtilmek üzere muhtemel karar alternatiflerinin herhangi birinin tercihi eşitlik 2 ile açıklanır.

$\mathrm{P}_{\mathrm{A}_{\mathrm{i}}}=\frac{1}{\mathrm{~m}}$

$\sum_{\mathrm{i}=1}^{\mathrm{m}} \mathrm{P}_{\mathrm{A}_{\mathrm{i}}}=1, \mathrm{i}=1,2, \ldots, \mathrm{m}$

Dolayısıyla karar alternatiflerin her birinin tercih olasılıkları birbirine eşittir.

$\mathrm{P}_{\mathrm{A}_{1}}=\mathrm{P}_{\mathrm{A}_{2}} \ldots . .=\mathrm{P}_{\mathrm{A}_{\mathrm{m}}}$

3. Aşama: Teorik Değerlendirme Matrisinin Sağlanması

Bu matris oluşturulurken kriter ağırlıkları ile tercih olasılıkları çarpılarak elde edilir.

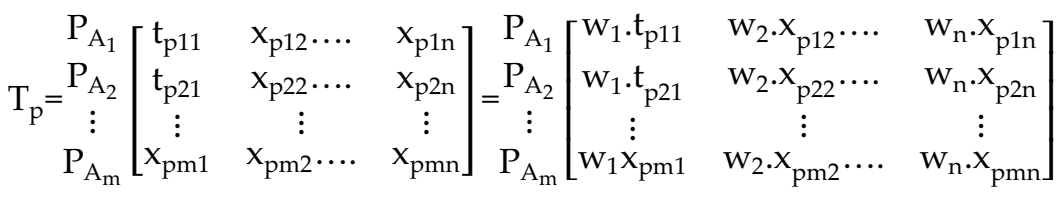

Buna göre, teorik değerlendirme matrisi eşitlik 5 ile sağlanır. Eşitlik 5 'te $n$ toplam kriter sayısını, $t_{p i}$ ise teorik değerini açıklamaktadır.

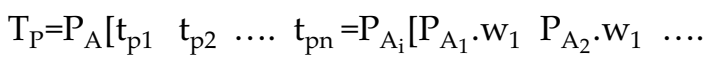

$\mathrm{P}_{\left.\mathrm{A}_{\mathrm{n}} \cdot \mathrm{W}_{\mathrm{n}}\right]}$

4. Aşama: Gerçek Değerlendirme Matrisinin Oluşturulması

Bu aşamada, öncelikle standartlaştırılmış matrisin sağlanması gerekmektedir. Standartlaştırılmış matris fayda yönlü (maksimizasyon) veya maliyet yönlü (minimizasyon) olmaktadır. Fayda yönlü kriterler için eşitlik 6, maliyet yönlü kriterler için ise eşitlik 7 ile standartlaştırılmış karar matrisi oluşturulur. 
$t_{r i j}=t_{p i j} \cdot\left(\frac{x_{i j}-x_{i}^{-}}{x_{i}^{+}-x_{i}^{-}}\right)$

$t_{\text {rij }}=t_{p i j} \cdot\left(\frac{x_{i}^{+}-x_{i j}}{x_{i}^{+}-x_{i}^{-}}\right)$

Eşitlik 6 ve eşitlik 7 'de bulunana $x_{i}^{+}$ilgili kriterlerin maksimum değerini belirtmektedir. $x_{i}^{-}$ise kriterlerin minimum değerini açıklamaktadır. Bu çerçevede eşitlik 8 ile gerçek değerlendirme matrisi belirlenir.

$$
\begin{aligned}
& C_{1}, \quad C_{2} \ldots C_{n}
\end{aligned}
$$

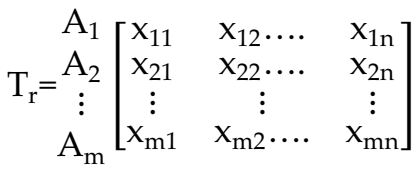

5. Aşama: Fark Matrisinin Hesaplanması

$$
\begin{aligned}
& \mathrm{G}=\mathrm{T}_{\mathrm{p}^{-}} \\
& \mathrm{T}_{\mathrm{r}}=\left[\begin{array}{ccc}
\mathrm{g}_{11} & \mathrm{~g}_{12} \cdots & \mathrm{g}_{1 \mathrm{n}} \\
\mathrm{g}_{21} & \mathrm{~g}_{22} \cdots & \mathrm{g}_{2 \mathrm{n}} \\
\vdots & \vdots & \vdots \\
\mathrm{g}_{\mathrm{m} 1} & \mathrm{~g}_{\mathrm{m} 2} \cdots & \mathrm{g}_{\mathrm{mn}}
\end{array}\right]=\left[\begin{array}{ccc}
\mathrm{t}_{\mathrm{p} 11}-\mathrm{t}_{\mathrm{r} 11} & \mathrm{t}_{\mathrm{p} 12}-\mathrm{t}_{\mathrm{r} 12} \cdots & \mathrm{t}_{\mathrm{p} 1 \mathrm{n}}-\mathrm{t}_{\mathrm{r} 1 \mathrm{n}} \\
\mathrm{t}_{\mathrm{p} 21}-\mathrm{t}_{\mathrm{r} 21} & \mathrm{t}_{\mathrm{p} 22}-\mathrm{t}_{\mathrm{r} 22} \cdots & \mathrm{t}_{\mathrm{p} 2 \mathrm{n}}-\mathrm{t}_{\mathrm{r} 2 \mathrm{n}} \\
\vdots & \vdots & \vdots \\
t_{\mathrm{pm} 1}-\mathrm{t}_{\mathrm{rm} 1} & \mathrm{t}_{\mathrm{pm} 2}-\mathrm{t}_{\mathrm{rm} 2} \cdots & \mathrm{t}_{\mathrm{pmn}}-\mathrm{t}_{\mathrm{rmn}}
\end{array}\right] \\
& f_{i j}=\left\{\begin{array}{lll}
0, & \text { eğer } & k_{\text {pij }}=k_{\text {rij }} \\
k_{\text {pij }}=k_{\text {rij }}, & \text { eğer } & k_{\text {pij }}>k_{\text {rij }}
\end{array}\right.
\end{aligned}
$$

6. Aşama: Karar Alternatiflere İlişkin Kriter Fonksiyon Değerlerinin (Performans Değerlerinin) Hesaplanması ve Sıralamaların Sağlanması

$\mathrm{Q}_{\mathrm{i}}=\sum_{\mathrm{j}=1}^{\mathrm{n}} \mathrm{g}_{\mathrm{ij}}$

Karar alternatifleri, ölçülen $Q_{i}$ değerlerine göre küçükten büyüğe doğru sıralanır. Diğer bir ifade ile $Q_{i}$ değeri en küçük olan en iyi ya da tercih edilebilir karar alternatifidir. Fakat $Q_{i}$ değeri en büyük olan ise en kötü karar alternatifidir.

\section{MARCOS Yöntemi}

MARCOS (Measurement of Alternatives and Ranking According to Compromise Solution Uzlaşık Çözüme Göre Alternatifleri Değerlendirme ve Sıralama) yöntemi, karar alternatifleri ile referans değerleri olan ideal ve anti-ideal alternatiflerin ilişkisini tespit ederek karar alternatiflerin performanslarını belirleyen bir ÇKKV yöntemidir. Söz konusu ilişkilerin temelinde karar alternatiflerinin fayda fonksiyonları hesaplanır ve ideal ve anti-ideal sonuçlara göre uzlaşık sıralama sağlanır. İdeal ve anti-ideal çözüm, fayda ve maliyet temelli kriterlere göre farklılık göstermektedir. Bu bakımdan fayda temelli açısından ideal çözüm, en büyük değeri alan karar alternatifidir. Buna karşın, maliyet kriterleri için ise ideal çözüm en küçük değere sahip olan karar alternatifidir. Aynı şekilde anti-ideal çözüm fayda kriterleri için en küçük, maliyet kriterleri için ise en büyük değeri alan karar alternatifidir. Kısaca, en iyi karar alternatifi ideal çözüme en yakın olan, anti-ideal çözüm ise ideal çözüme en uzak olan karar alternatifidir (Ecer, 2020: 338). Buna göre MARCOS yönteminin uygulama aşamaları aşağıda belirtilmiştir (Ecer, 2020: 339-342; Chattopadhyay vd., 2020: 56-58). 
1. Aşama: Karar Matrisinin Sağlanması

$X=\left[\begin{array}{ccc}x_{11} & x_{12} \ldots & x_{1 n} \\ x_{21} & x_{22} \ldots & x_{2 n} \\ \vdots & \vdots & \vdots \\ x_{\mathrm{m} 1} & x_{\mathrm{m} 2} \cdots & x_{\mathrm{mn}}\end{array}\right]$

2. Aşama: Genişletilmiş Karar Matrisinin Sağlanması

Genişletilmiş karar matrisi, karar matrisine ideal çözüm (Al) ve anti-ideal çözümün (AAl) eklenmesiyle oluşturulur. Söz konusu bu durum 13 ve eşitlik 14'de gösterilmiştir.

$$
\begin{aligned}
& \mathrm{C}_{\mathrm{n}} \\
& \mathrm{C}_{1}, \mathrm{C}_{2} \ldots \ldots
\end{aligned}
$$

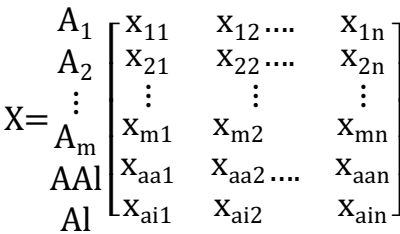

AI ve AAI değerlerinin ölçülmesi için fayda temelli kriterler için eşitlik 15, maliyet temelli kriterler için ise eşitlik $16^{\prime}$ dan yararlanılır.

$\left\{\begin{array}{c}A I=\min _{i} x_{i j}, \text { fayda temelli kriter ise }(j \in B) \\ A A I=m^{2} k_{i} x_{i j}, \text { fayda temelli kriter ise }(j \in B)\end{array}\right.$

$\left\{\begin{array}{l}A I=m^{2} k_{i} x_{i j}, \text { maliyet temelli kriter ise }(j \in C) \\ A A I=\min _{i} x_{i j}, \text { maliyet temelli kriter ise }(j \in C)\end{array}\right.$

3. Aşama: Genişletilmiş Karar Matrisinin Standartlaştırılması

Eşitlik 17 ile maliyet yönlü, eşitlik 18 ile fayda yönlü kriterler için eşitlik 19 ile genelleştirilmiş karar matrisinin standartlaştırılması sağlanır.

$n_{i j}=\frac{x_{i j}}{x_{a i}}, j \in B$

$n_{i j}=\frac{x_{a j}}{x_{i j}}, j \in C$

$\mathrm{N}=\left[\begin{array}{ccc}\mathrm{n}_{11} & \mathrm{n}_{12} \ldots & \mathrm{n}_{1 \mathrm{n}} \\ \mathrm{n}_{21} & \mathrm{n}_{22} \ldots & \mathrm{n}_{2 \mathrm{n}} \\ \vdots & \vdots & \vdots \\ \mathrm{n}_{\mathrm{m} 1} & \mathrm{n}_{\mathrm{m} 2} & \mathrm{n}_{\mathrm{mn}} \\ \mathrm{n}_{\mathrm{a} 1} & \mathrm{n}_{\mathrm{aa} 2} \ldots & \mathrm{n}_{\text {aan }} \\ \mathrm{n}_{\mathrm{a} 1} & \mathrm{n}_{\mathrm{a} 2} & \mathrm{n}_{\text {ain }}\end{array}\right]$

4. Aşama: Ağırlıklı Matrisin Sağlanması

$\mathrm{v}_{\mathrm{ij}}=\mathrm{n}_{\mathrm{ij}} \cdot \mathrm{w}_{\mathrm{j}}$

$\mathrm{V}=\left[\begin{array}{ccc}\mathrm{v}_{11} & \mathrm{v}_{12} \ldots . & \mathrm{v}_{1 \mathrm{n}} \\ \mathrm{v}_{21} & \mathrm{v}_{22} \ldots & \mathrm{v}_{2 \mathrm{n}} \\ \vdots & \vdots & \vdots \\ \mathrm{v}_{\mathrm{m} 1} & \mathrm{v}_{\mathrm{m} 2} & \mathrm{v}_{\mathrm{mn}} \\ \mathrm{v}_{\text {aa1 }} & \mathrm{v}_{\text {aa2 } 2 \ldots} \ldots & \mathrm{v}_{\text {aan }} \\ \mathrm{v}_{\text {ai1 }} & \mathrm{v}_{\text {ai2 } 2} & \mathrm{v}_{\text {ain }}\end{array}\right]$

5. Aşama: Karar Alternatiflerinin Fayda Derecelerinin Ölçülmesi

Ağırlıklı matrisin elemanlarının toplamı: 
$\mathrm{S}_{\mathrm{i}}=\sum_{\mathrm{i}=1}^{\mathrm{n}} \mathrm{v}_{\mathrm{ij}}$

Anti-ideal çözüme göre fayda derecesi:

$\mathrm{K}_{1}^{-}=\frac{\mathrm{S}_{\mathrm{i}}}{\mathrm{S}_{\text {aai }}}$

İdeal çözüme göre fayda derecesi:

$\mathrm{K}_{1}^{+}=\frac{\mathrm{S}_{\mathrm{i}}}{\mathrm{S}_{\mathrm{ai}}}$

6. Aşama: Karar Alternatiflerinin Fayda Fonksiyonlarının Tespiti

Anti-ideal çözüme göre fayda fonksiyonu

$f\left(K_{i}^{-}\right)=\frac{K_{i}^{+}}{K_{i}^{+}+K_{i}^{-}}$

İdeal çözüme göre fayda fonksiyonu

$f\left(K_{i}^{+}\right)=\frac{K_{i}^{-}}{K_{i}^{+}+K_{i}^{-}}$

7. Aşama: Alternatiflerin Fayda Fonksiyonların Belirlenmesi

$f\left(K_{i}\right)=\frac{K_{i}^{+}+K_{i}^{-}}{1+\frac{1-f\left(K_{i}^{+}\right)}{f\left(K_{i}^{+}\right)}+\frac{1-f\left(K_{i}^{-}\right)}{f\left(K_{i}^{-}\right)}}$

\section{BULGULAR}

Araştırmada ilk olarak MAIRCA yöntemi kapsamında eşitlik 1 ile karar matrisi oluşturulmuştur. Söz konusu karar matrisi Tablo 5'de gösterilmiştir.

Tablo 5. Karar Matrisi

\begin{tabular}{lcccc}
\hline Ülkeler & TTCI1 & TTCI2 & TTCI3 & TTCI4 \\
\hline Fransa & 5,6 & 4,8 & 5,4 & 5,9 \\
İtalya & 5,2 & 4,4 & 5 & 5,7 \\
İspanya & 5,5 & 4,9 & 5,6 & 5,7 \\
Portekiz & 5,5 & 4,8 & 5,2 & 4 \\
Türkiye & 4,6 & 4,5 & 4,4 & 3,3 \\
Yunanistan & 5,2 & 4,8 & 4,8 & 3,4 \\
Hirvatistan & 5,1 & 4,8 & 4,7 & 3,6 \\
Slovenya & 5,4 & 4,8 & 4,2 & 2,9 \\
Arnavutluk & 5 & 4,3 & 3,1 & 2 \\
Fas & 4,8 & 4,6 & 3,5 & 2,6 \\
Tunus & 4,7 & 4,5 & 3,1 & 2 \\
Cezayir & 4,6 & 3,6 & 2,3 & 2,1 \\
Misir & 4,5 & 4,6 & 3,3 & 3,1 \\
İsrail & 5,6 & 3,9 & 4,5 & 2 \\
GKRY & 5,5 & 4,7 & 4,6 & 2,1 \\
Malta & 5,6 & 4,9 & 4,7 & 2,2 \\
Lübnan & 4,5 & 4,3 & 3,1 & 1,7 \\
Bosna Hersek & 4,6 & 4,1 & 2,8 & 1,7 \\
Karadağ & 5,2 & 4,4 & 4 & 1,9 \\
\hline
\end{tabular}


MAIRCA yönteminde ikinci aşamada eşitlik 2 ve eşitlik 3 ile karar alternatiflerinin (ülkelerin) tercih değerleri tespit edilir. Tercih değerleri ülkelere karşılık gelen tüm bileşenler için 0,0526 olarak ölçülmüştür. Yöntemin üçüncü aşamasında eşitlik 4 ve eşitlik 5 ile teorik değerlendirme matris değerleri ölçülmüştür. Bu kapsamda söz konusu teorik matris değerleri tüm bileşenlerin ağırlık katsayıları 0,250 olduğu için 0,0132 olarak hesaplanmıştır. MAIRCA yönteminin dördüncü aşamasında eşitlik 6 ve eşitlik 8 ile gerçek değerlendirme matrisi değerleri tespit edilmiştir. Buna göre tespit edilen gerçek değerlendirme matris değerleri Tablo $6^{\prime}$ da gösterilmiştir.

Tablo 6. Gerçek Değerlendirme Matrisi

\begin{tabular}{lcccc}
\hline Ülkeler & TTCI1 & TTCI2 & TTCI3 & TTCI4 \\
\hline Fransa & 0,0132 & 0,01215 & 0,0124 & 0,0132 \\
İtalya & 0,0084 & 0,0081 & 0,0108 & 0,0125 \\
İspanya & 0,012 & 0,01316 & 0,0132 & 0,0125 \\
Portekiz & 0,012 & 0,01215 & 0,0116 & 0,0072 \\
Türkiye & 0,0012 & 0,00911 & 0,0084 & 0,005 \\
Yunanistan & 0,0084 & 0,01215 & 0,01 & 0,0053 \\
Hirvatistan & 0,0072 & 0,01215 & 0,0096 & 0,006 \\
Slovenya & 0,0108 & 0,01215 & 0,0076 & 0,0038 \\
Arnavutluk & 0,006 & 0,00709 & 0,0032 & 0,0009 \\
Fas & 0,0036 & 0,01012 & 0,0048 & 0,0028 \\
Tunus & 0,0024 & 0,00911 & 0,0032 & 0,0009 \\
Cezayir & 0,0012 & 0 & 0 & 0,0013 \\
Misir & 0 & 0,01012 & 0,004 & 0,0044 \\
İsrail & 0,0132 & 0,00304 & 0,0088 & 0,0009 \\
GKRY & 0,012 & 0,01113 & 0,0092 & 0,0013 \\
Malta & 0,0132 & 0,01316 & 0,0096 & 0,0016 \\
Lübnan & 0 & 0,00709 & 0,0032 & 0 \\
Bosna Hersek & 0,0012 & 0,00506 & 0,002 & 0 \\
Karadağ & 0,0084 & 0,0081 & 0,0068 & 0,0006 \\
\hline
\end{tabular}

5'inci aşamada eşitlik 9 ve eşitlik 10 ile fark matris değerleri belirlenmiştir. Yöntemin son aşamasında ise eşitlik 11 yardımıyla ülkelere ilişkin kriter fonksiyon (destinasyon rekabetçilik) performansları ölçülmüss ve ölçülen değerler sıralanmıştır. Bu kapsamda ölçülen fark matris ve ülkelerin destinasyon rekabetçilik performans değerleri ile söz konusu performans değerlerin sıralaması Tablo 7' de açıklanmıştır.

Tablo 7'ye göre, destinasyon rekabetçilik performansı en fazla olan ilk dört ülke Fransa, İspanya, Portekiz, İtalya son dört ülkenin ise Tunus, Lübnan, Bosna Hersek ve Cezayir olarak sıralanmıştır. Tablo 7 incelendiğinde, ortalama performans değerin nicel olarak altında olan Fransa, İspanya, Portekiz, İtalya, Malta, Yunanistan, Hirvatistan ve Slovenya, GKRY'nin, destinasyon rekabetçilik performans değerin nicel olarak üstünde olan ülkelere göre destinasyon rekabetçilik performansları daha fazladır. Özellikle Fransa ve İspanya ülkelerinin destinasyon rekabetçilik performansları, diğer ülkelerin destinasyon rekabetçilik performans değerleri arasında belirgin farklılıklar bulunmaktadır. 
Tablo 7. Fark Matris ve Ülkelerin Turizm Rekabet Performans Değerleri

\begin{tabular}{lcccccc}
\hline \multirow{2}{*}{ Ülkeler } & \multicolumn{2}{c}{ Fark Matrisi } & \multicolumn{2}{c}{ Değerler ve Siralama } \\
& TTCI1 & TTCI2 & TTCI3 & TTCI4 & Değerler & Siralama \\
\hline Fransa & 0 & 0,00101 & 0,0008 & 0 & 0,00181 & 1 \\
İtalya & 0,0048 & 0,00506 & 0,0024 & 0,0006 & 0,012864 & 4 \\
İspanya & 0,0012 & 0 & 0 & 0,0006 & 0,001823 & 2 \\
Portekiz & 0,0012 & 0,00101 & 0,0016 & 0,006 & 0,009756 & 3 \\
Türkiye & 0,012 & 0,00405 & 0,0048 & 0,0081 & 0,02894 & 12 \\
Yunanistan & 0,0048 & 0,00101 & 0,0032 & 0,0078 & 0,016819 & 6 \\
Hirvatistan & 0,006 & 0,00101 & 0,0036 & 0,0072 & 0,017787 & 7 \\
Slovenya & 0,0024 & 0,00101 & 0,0056 & 0,0094 & 0,018385 & 8 \\
Arnavutluk & 0,0072 & 0,00607 & 0,01 & 0,0122 & 0,035436 & 15 \\
Fas & 0,0096 & 0,00304 & 0,0084 & 0,0103 & 0,031317 & 13 \\
Tunus & 0,0108 & 0,00405 & 0,01 & 0,0122 & 0,037 & 16 \\
Cezayir & 0,012 & 0,01316 & 0,0132 & 0,0119 & 0,050182 & 19 \\
Misir & 0,0132 & 0,00304 & 0,0092 & 0,0088 & 0,034137 & 14 \\
İsrail & 0 & 0,01012 & 0,0044 & 0,0122 & 0,026725 & 10 \\
GKRY & 0,0012 & 0,00202 & 0,004 & 0,0119 & 0,019112 & 9 \\
Malta & 0 & 0 & 0,0036 & 0,0116 & 0,01518 & 5 \\
Lübnan & 0,0132 & 0,00607 & 0,01 & 0,0132 & 0,042357 & 17 \\
Bosna Hersek & 0,012 & 0,0081 & 0,0112 & 0,0132 & 0,044381 & 18 \\
Karadağ & 0,0048 & 0,00506 & 0,0064 & 0,0125 & 0,028756 & 11 \\
Ortalama & & & & & 0,023508 & \\
\hline
\end{tabular}

MARCOS yönteminin ilk aşamasında tıpkı MAIRCA yönteminde olduğu gibi karar matrisi oluşturulur. Söz konusu karar matrisi MAIRCA yönteminde daha öncesinden Tablo $6^{\prime}$ da gösterilmiştir. Yöntemin ikinci aşamasında eşitlik 14 ve eşitlik 15 ile genişletilmiş karar matris değerleri ölçülür. Ölçülen genişletilmiş karar matrisi değerleri Tablo 8'de sunulmuştur.

Tablo 8. Genişletilmiş Karar Matrisi

\begin{tabular}{lcccc}
\hline Ülkeler & TTCI1 & TTCI2 & TTCI3 & TTCI4 \\
\hline Fransa & 5,6 & 4,8 & 5,4 & 5,9 \\
İtalya & 5,2 & 4,4 & 5 & 5,7 \\
İspanya & 5,5 & 4,9 & 5,6 & 5,7 \\
Portekiz & 5,5 & 4,8 & 5,2 & 4 \\
Türkiye & 4,6 & 4,5 & 4,4 & 3,3 \\
Yunanistan & 5,2 & 4,8 & 4,8 & 3,4 \\
Hirvatistan & 5,1 & 4,8 & 4,7 & 3,6 \\
Slovenya & 5,4 & 4,8 & 4,2 & 2,9 \\
Arnavutluk & 5 & 4,3 & 3,1 & 2 \\
Fas & 4,8 & 4,6 & 3,5 & 2,6 \\
Tunus & 4,7 & 4,5 & 3,1 & 2 \\
Cezayir & 4,6 & 3,6 & 2,3 & 2,1 \\
Misır & 4,5 & 4,6 & 3,3 & 3,1 \\
İsrail & 5,6 & 3,9 & 4,5 & 2 \\
GKRY & 5,5 & 4,7 & 4,6 & 2,1 \\
Malta & 5,6 & 4,9 & 4,7 & 2,2 \\
Lübnan & 4,5 & 4,3 & 3,1 & 1,7 \\
Bosna Hersek & 4,6 & 4,1 & 2,8 & 1,7 \\
Karadağ & 5,2 & 4,4 & 4 & 1,9 \\
İdeal Çözüm & 5,6 & 4,9 & 5,6 & 5,9 \\
Anti-ideal Çözüm & 4,5 & 3,6 & 2,3 & 1,7 \\
\hline
\end{tabular}

MARCOS yönteminin üçüncü aşamasında Tablo 8'de belirtilen genişletilmiş karar matrisi değerleri eşitlik 16 ve eşitlik 18 yardımıyla standartlaştırılır. Buna göre, standartlaştırılmış karar matrisi Tablo 9'da gösterilmiştir. 
Tablo 9. Standartlaştırılmış Karar Matrisi

\begin{tabular}{lcccc}
\hline Ülkeler & TTCI1 & TTCI2 & TTCI3 & TTCI4 \\
\hline Fransa & 1 & 0,857143 & 0,964286 & 1,053571 \\
İtalya & 0,928571 & 0,785714 & 0,892857 & 1,017857 \\
İspanya & 0,982143 & 0,875 & 1 & 1,017857 \\
Portekiz & 0,982143 & 0,857143 & 0,928571 & 0,714286 \\
Türkiye & 0,821429 & 0,803571 & 0,785714 & 0,589286 \\
Yunanistan & 0,928571 & 0,857143 & 0,857143 & 0,607143 \\
Hirvatistan & 0,910714 & 0,857143 & 0,839286 & 0,642857 \\
Slovenya & 0,964286 & 0,857143 & 0,75 & 0,517857 \\
Arnavutluk & 0,892857 & 0,767857 & 0,553571 & 0,357143 \\
Fas & 0,857143 & 0,821429 & 0,625 & 0,464286 \\
Tunus & 0,839286 & 0,803571 & 0,553571 & 0,357143 \\
Cezayir & 0,821429 & 0,642857 & 0,410714 & 0,375 \\
Misır & 0,803571 & 0,821429 & 0,589286 & 0,553571 \\
İsrail & 1 & 0,696429 & 0,803571 & 0,357143 \\
GKRY & 0,982143 & 0,839286 & 0,821429 & 0,375 \\
Malta & 1 & 0,875 & 0,839286 & 0,392857 \\
Lübnan & 0,803571 & 0,767857 & 0,553571 & 0,303571 \\
Bosna Hersek & 0,821429 & 0,732143 & 0,5 & 0,303571 \\
Karadağ & 0,928571 & 0,785714 & 0,714286 & 0,339286 \\
İdeal Çözüm & 1 & 0,875 & 1 & 1,053571 \\
Anti-ideal Çözüm & 0,803571 & 0,642857 & 0,410714 & 0,303571 \\
\hline
\end{tabular}

Yöntemin dördüncü aşamasında eşitlik 19 ve eşitlik 20 yardımıyla ağırlıklı matris elde edilir. Buna göre hesaplanan ağırlıklı matris değerleri Tablo 10'da sunulmuştur.

Tablo 10. Ağırlıklı Matris

\begin{tabular}{lcccc}
\hline Ülkeler & TTCI1 & TTCI2 & TTCI3 & TTCI4 \\
w (Ağırlılar) & 0,25 & 0,25 & 0,25 & 0,25 \\
\hline Fransa & 0,25 & 0,214286 & 0,241071 & 0,263393 \\
İtalya & 0,232143 & 0,196429 & 0,223214 & 0,254464 \\
İspanya & 0,245536 & 0,21875 & 0,25 & 0,254464 \\
Portekiz & 0,245536 & 0,214286 & 0,232143 & 0,178571 \\
Türkiye & 0,205357 & 0,200893 & 0,196429 & 0,147321 \\
Yunanistan & 0,232143 & 0,214286 & 0,214286 & 0,151786 \\
Hirvatistan & 0,227679 & 0,214286 & 0,209821 & 0,160714 \\
Slovenya & 0,241071 & 0,214286 & 0,1875 & 0,129464 \\
Arnavutluk & 0,223214 & 0,191964 & 0,138393 & 0,089286 \\
Fas & 0,214286 & 0,205357 & 0,15625 & 0,116071 \\
Tunus & 0,209821 & 0,200893 & 0,138393 & 0,089286 \\
Cezayir & 0,205357 & 0,160714 & 0,102679 & 0,09375 \\
Misır & 0,200893 & 0,205357 & 0,147321 & 0,138393 \\
İsrail & 0,25 & 0,174107 & 0,200893 & 0,089286 \\
GKRY & 0,245536 & 0,209821 & 0,205357 & 0,09375 \\
Malta & 0,25 & 0,21875 & 0,209821 & 0,098214 \\
Lübnan & 0,200893 & 0,191964 & 0,138393 & 0,075893 \\
Bosna Hersek & 0,205357 & 0,183036 & 0,125 & 0,075893 \\
Karadağ & 0,232143 & 0,196429 & 0,178571 & 0,084821 \\
İdeal Çözüm & 0,25 & 0,21875 & 0,25 & 0,263393 \\
Anti-ideal Çözüm & 0,200893 & 0,160714 & 0,102679 & 0,075893 \\
\hline
\end{tabular}


Yöntemin 5'inci aşamasında ülkelerin fayda dereceleri kapsamında eşitlik 21 ile ağırlıklı toplam matrisinin elemanlarının toplamı $\left(\mathrm{S}_{\mathrm{i}}\right)$, eşitlik 22 ile ideal çözüm fayda derecesi $\left(\mathrm{K}_{\mathrm{i}}^{-}\right)$ve eşitlik 23 ile anti ideal çözüm fayda derecesi $\left(K_{i}^{+}\right)$hesaplanmaktadır. Bu göre ülkelere ait $S_{i}, K_{i}^{-}$ve $\mathrm{K}_{\mathrm{i}}^{+}$değerleri Tablo $11^{\prime}$ de gösterilmiştir.

Tablo 11. $S_{i}, K_{i}^{-}$ve $K_{i}^{+}$Değerleri

\begin{tabular}{lccc}
\hline Ülkeler & $\mathrm{S}_{\mathrm{i}}$ & $\mathrm{K}_{\mathrm{i}}^{+}$ & $\mathrm{K}_{\mathrm{i}}^{-}$ \\
\hline Fransa & 0,96875 & 0,986364 & 1,793388 \\
İtalya & 0,90625 & 0,922727 & 1,677686 \\
İspanya & 0,96875 & 0,986364 & 1,793388 \\
Portekiz & 0,870536 & 0,886364 & 1,61157 \\
Türkiye & 0,75 & 0,763636 & 1,38843 \\
Yunanistan & 0,8125 & 0,827273 & 1,504132 \\
Hırvatistan & 0,8125 & 0,827273 & 1,504132 \\
Slovenya & 0,772321 & 0,786364 & 1,429752 \\
Arnavutluk & 0,642857 & 0,654545 & 1,190083 \\
Fas & 0,691964 & 0,704545 & 1,280992 \\
Tunus & 0,638393 & 0,65 & 1,181818 \\
Cezayir & 0,5625 & 0,572727 & 1,041322 \\
Misır & 0,691964 & 0,704545 & 1,280992 \\
İsrail & 0,714286 & 0,727273 & 1,322314 \\
GKRY & 0,754464 & 0,768182 & 1,396694 \\
Malta & 0,776786 & 0,790909 & 1,438017 \\
Lübnan & 0,607143 & 0,618182 & 1,123967 \\
Bosna Hersek & 0,589286 & 0,6 & 1,090909 \\
Karadağ & 0,691964 & 0,704545 & 1,280992 \\
İdeal Çözüm & 0,982143 & 1 & 1,818182 \\
Anti-ideal Çözüm & 0,540179 & 0,55 & 1 \\
\hline
\end{tabular}

Yöntemin $6^{\prime}$ incı aşamasında ülkelerin fayda ideal ve anti ideal fayda fonksiyon değeri $\left(f\left(K_{i}^{-}\right)\right)$ eşitlik 24, ideal fonksiyon değeri $\left(f\left(K_{i}^{+}\right)\right)$eşitlik 25 ve ülkelerin destinasyon rekabetçilik performansı (ülkelerin uzlaşık çözümü $=\mathrm{f}\left(\mathrm{K}_{\mathrm{i}}\right)$ ) eşitlik 26 ile hesaplanır. Bu kapsamda ölçülen $\mathrm{f}\left(\mathrm{K}_{\mathrm{i}}^{-}\right)$, $f\left(K_{i}^{+}\right), f\left(K_{i}\right)$ değerleri ile $f\left(K_{i}\right)$ değerlerinin sıralaması Tablo 12' de açıklanmıştır.

Tablo 12 incelendiğinde, destinasyon rekabetçilik performansı en fazla olan ilk dört ülkenin İspanya, Fransa, İtalya ve Portekiz, destinasyon rekabetçilik performansı en az olan ilk dört ülkenin ise Arnavutluk, Tunus, Lübnan ve Cezayir olduğu gözlenmiştir. Ayrıca Tablo 12'ye göre, ortalama destinasyon rekabetçilik performans değerinin üstünde olan ülkeler MAIRCA kapsamı (Fransa, İspanya, Portekiz, İtalya, Malta, Yunanistan, Hırvatistan, Slovenya) haricinde GKRY'nin olduğu gözlenmiştir. Bütünsel olarak değerlendirildiğinde, her iki yönteme göre Fransa, İspanya, Portekiz, İtalya, Malta, Yunanistan, Hirvatistan, Slovenya ortalama turizm rekabetçilik performansı üstünde, buna karşın Türkiye, İsrail, Fas, Mısır, Arnavutluk, Tunus, Lübnan ve Cezayir her iki yönteme göre ortalama turizm rekabetçilik performansı altında olduğu tespit edilmiştir. Ayrıca Türkiye'nin her iki yönteme göre turizm rekabetçilik performans ortalama değerine yakın değerde olduğu tespit edilmiştir. Bunun dışında, GKRY'nin turizm performans rekabet ortalaması MAIRCA yöntemine göre ortalama performans değerinin üstünde, fakat MARCOS yöntemine göre düşük olduğu için her iki yöntem açısından GKRY kesişim dışı kalmıştır. 
Tablo 12. $f\left(K_{i}^{-}\right), f\left(K_{i}^{+}\right), f\left(K_{i}\right)$ Değerleri

\begin{tabular}{lcccc}
\hline Ülkeler & $\mathrm{f}\left(\mathrm{K}_{\mathrm{i}}^{+}\right)$ & $\mathrm{f}\left(\mathrm{K}_{\mathrm{i}}^{-}\right)$ & $\mathrm{f}\left(\mathrm{K}_{\mathrm{i}}\right)$ & Siralama \\
\hline Fransa & 0,645161 & 0,354839 & 0,825298 & 1 \\
İtalya & 0,645161 & 0,354839 & 0,772053 & 3 \\
İspanya & 0,645161 & 0,354839 & 0,825298 & 1 \\
Portekiz & 0,645161 & 0,354839 & 0,741627 & 4 \\
Türkiye & 0,645161 & 0,354839 & 0,63894 & 10 \\
Yunanistan & 0,645161 & 0,354839 & 0,692185 & 5 \\
Hirvatistan & 0,645161 & 0,354839 & 0,692185 & 6 \\
Slovenya & 0,645161 & 0,354839 & 0,657956 & 8 \\
Arnavutluk & 0,645161 & 0,354839 & 0,547663 & 15 \\
Fas & 0,645161 & 0,354839 & 0,589498 & 12 \\
Tunus & 0,645161 & 0,354839 & 0,54386 & 16 \\
Cezayir & 0,645161 & 0,354839 & 0,479205 & 19 \\
Misır & 0,645161 & 0,354839 & 0,589498 & 12 \\
İsrail & 0,645161 & 0,354839 & 0,608514 & 11 \\
GKRY & 0,645161 & 0,354839 & 0,642743 & 9 \\
Malta & 0,645161 & 0,354839 & 0,661759 & 7 \\
Lübnan & 0,645161 & 0,354839 & 0,517237 & 17 \\
Bosna Hersek & 0,645161 & 0,354839 & 0,502024 & 18 \\
Karadağ & 0,645161 & 0,354839 & 0,589498 & 12 \\
& & Ortalama & 0,64856 & \\
\hline
\end{tabular}

Araştırma kapsamında ayrıca ülkelerin TTCI ile MAIRCA ve MARCOS yöntemleri sonucunda ölçülen turizm rekabetçilik performans değerleri arasındaki korelasyon değerleri ölçülmüştür. Söz konusu korelasyon katsayıları Tablo 13’de gösterilmiştir.

Tablo 13. Yöntemler Arasındaki Pearson Korelasyon Katsayıları

\begin{tabular}{cccc}
\hline Yöntemler & TTCI & MAIRCA & MARCOS \\
\hline TTCI & ----- & ----- & ----- \\
MAIRCA & $-0,973^{* *}$ & 1 & ---- \\
MARCOS & $0,999^{* *}$ & $-0,973^{* *}$ & ---- \\
\hline${ }^{* *} \mathrm{p}<.01$ & & &
\end{tabular}

Tablo 13'e göre, TTCI değerleri MAIRCA ile anlamlı, negatif yönlü ve çok yüksek, MARCOS yöntemi ile anlaml, pozitif yönlü ve çok yüksek ilişki tespit edilmiştir. MAIRCA yönteminde küçük olan değerler performans değerinin fazla olması anlamına geldiğinden dolayı MAIRCA yöntemi MARCOS yöntemi ile aslında pozitif yönde ilişki kurduğu değerlendirilebilir. Bu durum, TTCI'nın MAIRCA ve MARCOS yöntemleri ile açıklanabileceğini göstermektedir. Ayrıca TTCI değerleri MAIRCA yöntemi değerlerinden daha çok MARCOS yöntemi değerleri ile ilişki içinde olduğundan dolayı TTCI değerleri MAIRCA yöntemine kıyasla MARCOS yöntemi ile daha iyi açıklanabileceği değerlendirilebilir. Bunların dışında, MAIRCA değerleri ve MARCOS değerleri arasındaki ilişki değerlerinin anlamlı, negatif yönlü ve çok yüksek seviyede ilişki olması kapsamında MAIRCA yönteminde küçük olan değerler performans değerinin fazla olması anlamına geldiğinden dolayı söz konusu her iki yöntemin benzer olduğu söylenebilir. 


\section{SONUÇ, TARTIŞMA ve ÖNERI}

Ülkelerin küresel anlamda destinasyon rekabetçilik performanslarının farkında olmasıyla, ülkeler turizm rekabet performanslarını artıracak stratejiler ve faaliyetler gerçekleştirebilmektedirler. Ayrıca ülkelerin birbirlerinin destinasyon rekabetçilik performanslarını takip ederek destinasyon rekabetçilik performansı iyi olan ülkeler destinasyon rekabetçilik performansı artırımı konusunda eşgüdüm sağlayabilmektedirler. Dolayısıyla ülkelerin uluslararası alanda destinasyon rekabetçilik performanslarının ölçümü büyük önem arz etmektedir. Bu kapsamda araştırmada, en son ve güncel olan 2019 yılı için Seyahat ve Turizm Rekabetçilik Endeksi raporunda Akdeniz'e sınırı olan 19 ülkenin destinasyon rekabetçilik performansları MAIRCA ve MARCOS yöntemler ile ölçülmüştür.

Bulgulara göre, MAIRCA ve MARCOS yöntemleri kapsamında ülkelerin destinasyon rekabetçilik performansları açısından İspanya, İtalya, Fransa ve Portekiz ilk dört; Cezayir, Lübnan, Tunus ve Arnavutluk ise son dört ülke içinde olduğu tespit edilmiştir. Bunun yanında MAIRCA ve MARCOS yöntemlerine göre; Fransa, İspanya, Portekiz, İtalya, Malta, Yunanistan, Hırvatistan ve Slovenya'nın destinasyon rekabetçilik performans değerleri, ortalama destinasyon rekabetçilik performans değerinden yüksek çıkmıştır. MARCOS yöntemi kapsamında ayrıca GKRY'nin destinasyon rekabetçilik performans değeri ortalama değerden fazla olduğu gözlenmiştir. Bunun dışında, Türkiye'nin her iki yönteme göre ortalama destinasyon rekabetçilik performans değerine çok yakın olduğu gözlenmiştir.

Diğer bir bulguya göre, TTCI'nın MAIRCA yöntemi kapsamında ülkelerin destinasyon rekabetçilik performans değerleri arasında anlamlı, negatif yönlü ve çok yüksek ilişkiler olduğu tespit edilmiştir. MAIRCA yönteminde küçük olan değerler performans değerinin fazla olması anlamına geldiğinden dolayı MAIRCA yönteminin MARCOS yöntemi ile aslında pozitif yönde ilişkisi olduğu söylenebilir. Yine bulgulara göre, TTCI MARCOS yöntemleri kapsamında ülkelerin destinasyon rekabetçilik performans değerleri arasında anlamlı, pozitif yönlü ve çok yüksek seviyede ilişki olduğu tespit edilmiştir. Dolayısıyla bu durum, TTCI'nın MAIRCA ve MARCOS yöntemleri ile açılanabileceğini göstermektedir. Bunun yanında, MAIRCA ve MARCOS yöntemleri ile tespit edilen ülkelerin destinasyon rekabetçilik performans değerleri arasında anlamlı, negatif yönlü ve çok yüksek ilişki tespit edilmiştir. Yine MAIRCA yönteminde küçük değerler performans değerinin fazla olmasını göstermesinden dolayı aslında MAIRCA ve MARCOS yöntemleri ile tespit edilen ülkelerin destinasyon rekabetçilik performans değerleri arasında pozitif yönlü ilişki olduğu düşünülmüştür. Dolayısıyla MAIRCA ve MARCOS metotları birbirlerine yöntem kapsamında benzemektedir.

Literatür değerlendirildiğinde, Manap ve Davraz'ın (2020) çalışmasında 2019 yılı için 16 Akdeniz ülkesinin TTCI kapsamında TOPSIS ve VIKOR yöntemler ile bütünleşik olarak destinasyon rekabetçilik performansları fazla olan ülkelerin İspanya, Fransa ve Yunanistan, en az olan ülkelerin ise Lübnan, İsrail ve Cezayir olduğu tespit edilmiştir. Güllü ve Yılmaz (2020) araştırmasında 2019 yılı için 10 Akdeniz ülkesinin TTCI kapsamında ENTROPİ tabanlı EDAS yöntemi ile destinasyon rekabetçilik performansı en fazla olan dört ülkenin Fransa, İspanya, İtalya ve Portekiz olduğunu belirlemişlerdir. Bu araştırmada 2019 yılı için 19 Akdeniz ülkesinin TTCI kapsamında MAIRCA ve MARCOS yöntemlerine göre bütünsel olarak en fazla destinasyon rekabetçilik performansı sergileyen ilk dört ülkenin İspanya, Fransa, İtalya ve Portekiz olduğu tespit edilmiştir. Dolayısıyla bu çalışmada tespit edilen bulgular ile Güllü ve Yılmaz'ın (2020) çalışmasındaki bulgular, Manap ve Davraz'ın (2020) çalışmasındaki bulgulara göre daha fazla tutarlılık göstermiştir. Her üç çalışma bütünsel olarak düşünüldüğünde, İspanya ve Fransa'nın kararlı bir destinasyon rekabetçilik performansının olduğu söylenebilir. Ayrıca hem bu 
çalışmada hem de Manap ve Davraz'ın (2020) çalışmasında yöntemlere göre Cezayir'in en az destinasyon rekabetçilik değerine sahip olması dikkat çekicidir.

Öneriler kapsamında ilk olarak MAIRCA ve MARCOS yöntemleri ile ortalama destinasyon rekabetçilik performans değerinin altında kalan Türkiye, İsrail, Fas, Mısır, Arnavutluk, Tunus, Lübnan ve Cezayir'in destinasyon rekabetçiliği konusunda diğer ülkeler ile rekabet edebilmesi için kendi destinasyon rekabetçilik performanslarını artııcı stratejiler ve politikalar geliştirmelidirler. Böylelikle Akdeniz bölgesine kıyısı olan ülkelerin rekabet durumu daha kaliteli olabilecek ve ülkeler kendi ekonomilerine ve küresel ekonomiye katkıları daha fazla sağlayabileceklerdir. Bunun yanında ülkeler arası oluşan rekabet ile turizm konusunda hizmet kalitesi artabilecek ve turistlerin dünya çapında ilgi odağı Akdeniz'e kıyısı olan ülkeler olabilecektir. Ayrıca TTCI bileşenlerinin birbirlerini tamamlaması kapsamında, ülkeler söz konusu bileşenlerin birbirleri ilgilendirecek, oluşturacak ve sağlayacak faaliyetler gerçekleştirerek ülkeler destinasyon rekabetçilik performanslarını artırabilirler. Bunların dışında Akdeniz ülkeleri kendilerine özgü kültür doğrultusunda turizm politikalarını geliştirerek destinasyon rekabetçilik konusunda sürdürülebilirlik sağlayabileceklerdir. Yöntem kapsamında ise gelecek çalışmalarda ülkelerin destinasyon rekabetçilik performansları farklı ÇKKV yöntemleri ile ölçülerek yöntemler sonucu elde edilen sonuçlar karşılaştırılabilir ve tartışılabilir. Bunun yanında, dünya üzerinde farklı bölgelerde mevcut ülkelerin destinasyon rekabetçilik performansları ölçülebilir ve ölçülen performans değerleri bölgeler bazında karşılaştırılabilir. Bunların dışında TTCI'nın ülkelerin destinasyon rekabetçilik performanslarını ölçmesinin daha gerçekçi olması kapsamında ülkelere standart bileşenler yerine her ülkeye özgü TTCI bileşenleri belirlenebilir ya da bileşen sayısı artırılabilir.

\section{KAYNAKÇA}

Aksoy, E. (2021). An Analysis on Turkey's Merger and Acquisition Activities: MAIRCA Method. Gümüşhane Üniversitesi Sosyal Bilimler Enstitüsü Elektronik Dergisi, 12(1), 1-11.

Ayçin, E. ve Güçlü, P. (2020). BIST Ticaret Endeksinde Yer Alan İşletmelerin Finansal Performanslarının Entropi ve MAIRCA Yöntemleri ile Değerlendirilmesi. Muhasebe ve Finansman Dergisi(85), 287-312.

Ayçin, E. ve Orçun, Ç. (2019). Mevduat Bankalarının Performanslarının ENTROPI ve MAIRCA Yöntemleri ile Değerlendirilmesi. Balıkesir Üniversitesi Sosyal Bilimler Enstitüsü Dergisi, 22(42), 175194.

Badi, I., and Pamućar, D. (2020). Supplier Selection for Steelmaking Company by Using Combined Grey-MARCOS Methods. Decision Making: Applications in Management and Engineering, $3(2), 37-47$.

Benedetti, J. (2010). The Competitiveness of Brazil as a Dutch Holiday Destination. Master Thesis, NHTV University of Applied Sciences, Breda.

Boral, S., Howard, I., Chaturvedi, S. K., McKee, K., and Naikana, V. (2020). An Integrated Approach for Fuzzy Failure Modes and Effects Analysis Using Fuzzy AHP and Fuzzy MAIRCA. Engineering Failure Analysis, 108, 1-16.

Božanić, D., Jurišić, D., and Erkić, D. (2020). LBWA Z MAIRCA Model Supporting Decision Making in the Army. Operational Research in Engineering Sciences: Theory and Applications, 3(2), 87110. 
Bozok, D. ve Köroglu, A. (2007). Akdeniz Ülkelerine Yönelik Uluslararası Turizm Hareketleri. Ticaret ve Turizm Egitim Fakültesi Dergisi, 1, 146-157.

Bucher, S. (2018). The Global Competitiveness Index As an Indicator of Sustainable Development. Herald of the Russian Academy of Sciences, 88, 44-57.

Buhalis, D. (2000). Marketing the Competitive Destination of the Future. Tourism Management, 21, 97-116.

Chatterjee, K., Pamućar, D., and Zavadskas, E. K. (2018). Evaluating the Performance of Suppliers Based on Using the R'AMATEL-MAIRCA Method for Green Supply Chain Implementation in Electronics Industry. Journal of Cleaner Production, 184, 101-129.

Chattopadhyay, R., Chakraborty, S., and Chakraborty, S. (2020). An Integrated D-MARCOS Method for Supplier Selection in An Iron and Steel Industry. Decision Making: Applications in Management and Engineering, 3(2), 49-69.

Cibinskiene, A., and Snieskiene, G. (2015). Evaluation of City Tourism Competitiveness. Procedia - Social and Behavioral Sciences, 213, 105-110.

Croitoru, M. (2011). Tourism Competitiveness Index - An Empirical Analysis Romania vs. Bulgaria. Theoretical and Applied Economics, 28(9), 155-172.

Crotti, R., Misrahi, T., and WEF. (2015). The Travel \& Tourism Competitiveness Index 2015: T\&T as a Resilient Contribution to National Development. in WEF, The Travel \& Tourism Competitiveness Index 2015, Geneva: WEF, 3-28.

Croutch, G. I., and Ritchie, J. (1994). Destination Competitiveness: Exploring Foundations for a Long Term Research Program . Administrative Science Associations. Halifax, 79-88.

Croutch, G. I., and Ritchie, J. (1995). Destination Competitiveness Models and The Role of The Tourism Enterprise. 4. Annual World Business Congress. İstanbul, 440-448.

Croutch, G. I., and Ritchie, J. R. (1999). Tourism, Competitiveness and Societal Prosperity. Journal of Business Research, 44(3), 137-152.

Dwyer, L., and Kim, C. (2003). Destination Competitiveness: A Model and Determinants. Current Issues in Tourism, 6(5), 369-414.

Dwyer, L., Forsyth, P., and Dwyer, W. (2020). Compettiveness Index as Tool for Economic Development and Poverty Reduction. in L. Moutinho, Strategic Management in Tourism. Sao Paulo: CABI Tourism Texts, 33-45.

Ecer, F. (2020). Çok Kriterli Karar Verme. Ankara: Seçkin Yayıncılık.

Ekin, Y. (2004). Turizm Paydaşları Persfektifinden Turizm Gelişimi ve Destinasyon Rekabetçiliği. Akdeniz Üniversitesi Sosyal Bilimler Enstitüsü, Yayınlanmamış Yüksek Lisans Tezi, Antalya.

Eşiyok, H., ve Hassan, A. (2020). Akdeniz Çanağındaki Destinasyonların Seyahat ve Turizm Rekabetçilik Endeksi Verilerinin Rekabette Karşılaştırmalı Üstünlükler Teorisine Göre İncelenmesi. IITD 20 International Travel and Tourism Dynamics Congress. Ankara: Ankara Hacı Bayram Veli Universitesi, 1-10.

Gabor, M. R., Contiu, L., and Oltean, F. D. (2012). A Comparative Analysis Regarding European Tourism Competitiveness: Emerging Versus Developed Markets. Procedia Economics and Finance, $3,361-366$. 
Gigovic, L., Pamućar, D., Bajic, Z., and Milicevic, M. (2016). The Combination of Expert Judgment and GIS-MAIRCA Analysis for the Selection of Sites for Ammunition Depots. Sustainability, 8, 130.

Gigovic, L., Pamućar, D., Bajic, Z., and Milicevic, M. (2019). The Combination of Expert Judgment and GIS-MAIRCA Analysis for the Selection of Sites for Ammunition Depots. Sustainability, 8, 130 .

Gooroochurn, N., and Sugiyarto, G. (2005). Competitiveness Indicators in the Travel and Industry. Tourism Economics, 11(1), 25-43.

Göral, R. (2016). Turizm Destinasyonu Rekabetçilik Faktörleri ve Entropi Yöntemİyle AğIrlIklandırılması. Ekonomi ve Yönetim Araştırmaları Dergisi, 5(2), 66-81.

Göral, R., and Yurtlu, M. (2021). Uluslararası Seyahat ve Turizm Rekabetçilik Endeksi Kapsamında Türkiye'nin Güçlü ve Zayıf Yönlerinin Değerlendirilmesi. Sosyal, Beşerî ve İdari Bilimler Dergisi, 4(6), 544-576.

Güllü, K., and Yılmaz, M. (2020). Determination of Destination Competitiveness of The Selected Mediterranean Destinations by ENTROPY Based EDAS Method. Erciyes Üniversitesi Sosyal Bilimler Enstitüsü Dergisi, 48(1), 486-509.

Hassan, S. (2000). Determinants of Market Competitiveness in An Environmentally Sustainable Tourism Industry. Journal of Travel Research, 38(3), 239- 245.

Heath, E. (2002). Towards a Model to Enhance Africa's Sustainable Tourism Competitiveness. Journal of Public Administiration, 37(1), 327-353.

Heath, E. (2003). Towards A Model Enhance Destination Competitiveness: A Southern African Perspective. Journal of Hospitality and Tourism Manegement, 37(3), 327-353.

Khan, S., Qianli, D., SongBo, W., Zaman, K., and Zhang, Y. (2017). Travel and TourismCompetitiveness Index: The Impact of Air Transportation, Railways Transportation, Travel and Transport Services on International Inbound and Outbound Tourism. Journal of Air Transport Management, 58, 125-134.

Kim, C., and Dwyer, L. (2003). Destination Competitiveness and Bilateral Flows between Australia and Korea. Journal of Tourism Studies, 14(2), 54-67.

Krstic, B., Jovanovic, S., Jankovic-Milic, V., and Stanisic, T. (2016). Examination of Travel and Tourism Competitiveness Contribution to National Economy Competitiveness of Sub-Saharan Africa Countries. Development Southern Africa, 33(4)1-16. DOI:10.1080/0376835X.2016.1179103

Manap Davras, G. (2020). Akdeniz Turizm Destinasyonlarının Rekabet Gücü Açısından TOPSIS ve VIKOR Yöntemleri ile Karşılaştırılması. Journal of Tourism and Gastronomy Studies, 8(2), 14391456.

Meessen, K. M. (2009). Prinzip Wettbewerb. Juristen Zeitung,14, 697-706.

Nazmfar, H., Eshghei, A., Alavi, S., and Pourmoradian, S. (2019). Analysis of Travel and Tourism Competitiveness Index in Middle-East Countries. Asia Pacific Journal of Tourism Research, 24(6), 501-513.

Pamućar, D., Mihajlovic, M., Obradovic, R., and Atanaskovic, P. (2017). Novel Approach to Group Multi-Criteria Decision Making Based on Interval Rough Numbers: Hybrid DEMATELANP-MAIRCA Model. Expert Systems With Applications, 88, 58-80. 
Pulido-Fernández, J., and Rodríguez-Díaz, B. (2016). Reinterpreting the World Economic Forum's Global Tourism Competitiveness Index. Tourism Management Perspectives, 20, 131-140.

Ritchie, J., and Crouch, G. I. (2003). The Competitive Destination: A Sustainable Tourism Perspective. Wallingford: CABI Publishing.

Ritchie, J., and Croutch, G. I. (1993). Competitiveness in International Tourism: A Framework for Understanding and Analysis. 43. Congress of the Association Internationale d'Experts Scientifique du Tourisme. San Carlos de Bariloche, 23-71.

Ritchie, J., and Croutch, G. I. (2000). The Competitive Destination: A Sustainability Perfective. Tourism Management, 21(1), 1-7.

Stević, Ž., and Brković, N. (2020). A Novel Integrated FUCOM-MARCOS Model for Evaluation of Human Resources in a Transport Company. Logistics, 4(4), 1-14.

Stević, Ž., Pamučar, D., Puškac, A., and Chatterjee, P. (2020). Sustainable Supplier Selection in Healthcare Industries Using a New MCDM method: Measurement of Alternatives and Ranking According to COmpromise Solution (MARCOS). Computers \& Industrial Engineering, 140, 1-15.

Tesić, D., and Bozanić, D. (2008). Primena Metode MAIRCA pri Izboru Mesta za Prelazak Tenkova pod Vodom. Tehnika Menadzment, 68(6), 860-867.

Ulutaş, A. (2019). Swara ve Mairca Yöntemleri İle Catering Firması Seçimi. BMIJ, 7(4), 1467-1479.

Ulutaş, A., Karabasevic, D., Popovic, G., Stanujkic, D., Nguyen, P. T. ve Karaköy, Ç. (2020). Development of a Novel Integrated CCSD-ITARA-MARCOS Decision-Making Approach. Mathematics, 8, 1-15.

Vengesayi, S. (2003). A Conceptual Model of Tourism Destination Competitiveness and Attractiveness . ANZMAC. Adelaide.

WEF. (2007). The Travel \& Tourism Competitiveness Report 2007 Furthering the Process of Economic Development. Geneva: WEF.

WEF. (2008). The Travel \& Tourism Competitiveness Report 2008 Balancing Economic Development and Environmental Sustainability. Geneva: WEF.

WEF. (2009). The Travel \& Tourism Competitiveness Report 2009 Managing in a Time of Turbulence. Geneva: WEF.

WEF. (2011). The Travel \& Tourism Competitiveness Report 2011 Beyond the Downturn. Genova: WEF. WEF. (2013). The Travel \& Tourism Competitiveness Report 2013 Reducing Barriers to Economic Growth and Job Creation. Genova: WEF.

WEF. (2015). The Travel \& Tourism Competitiveness Report 2015 Growth through Shocks. Genova : WEF.

WEF. (2017). The Travel \& Tourism Competitiveness Report 2017 Paving the way for a more sustainable and inclusive future. Genova: WEF.

WEF. (2019). The Travel \& Tourism Competitiveness Report 2019 Travel and Tourism at a Tipping Point. Geneva: WEF.

WEF. (2019). The Travel \& Tourism Competitiveness Report 2019 Travel and Tourism at a Tipping Point. Genova: WEF. 
Yoon, Y. (2002). Development of Structural Model for Tourism Destination Competitiveness from Stakeholders' Perferctives. Yayımlanmamış doktora tezi, Tke Virgina Polytechnic Institute and State University, Virginia.

Zolfani, S. H., Chatterjee, P., and Yazdani, M. (2019). A Structured Framework for Sustainable Supplier Selection Using A Combined BWM-COCOSO Model. International Scientific Conference Contemporary Issues in Business, Management and Economics Engineering 2019. Vilnius: Vilnius Tech., 797-804. 